Cahiers $d u$ MONDE RUSSE

\section{Cahiers du monde russe}

Russie - Empire russe - Union soviétique et États indépendants

$44 / 1 \mid 2003$

Varia

\title{
«Byvšie» v uslovijah NEPA : «širokie perspektivy» ili novye problemy?
}

\section{Tat'jana SMIRNOVA}

\section{OpenEdition}

\section{Journals}

Édition électronique

URL : https://journals.openedition.org/monderusse/8601

DOI : 10.4000/monderusse.8601

ISSN : $1777-5388$

\section{Éditeur}

Éditions de l'EHESS

\section{Édition imprimée}

Date de publication : 1 janvier 2003

Pagination : 111-134

ISBN : 2-7132-1812-8

ISSN : $1252-6576$

Référence électronique

Tat'jana SMIRNOVA, « «Byvšie» v uslovijah NEPA : «Širokie perspektivy» ili novye problemy? », Cahiers du monde russe [En ligne], 44/1 | 2003, mis en ligne le 01 janvier 2007, consulté le 04 septembre 2022 URL : http://journals.openedition.org/monderusse/8601; DOI : https://doi.org/10.4000/monderusse. 8601 


\title{
CAIR N
}

chercher : repérer : avancer

Cet article est disponible en ligne à l'adresse :

http://www.cairn.info/article.php?ID REVUE=CMR\&ID NUMPUBLIE=CMR 441\&ID ARTICLE=CMR 441 O111

\section{"Byvsie" v uslovijah NEPA : "sirokie perspektivy" ili novye problemy ?}

\author{
par Tat' jana SMIRNOVA
}

\section{| Editions de l'EHESS | Cahiers du monde russe}

\author{
2003/1 - Vol 44 \\ ISSN 1252-6576 | ISBN 2713218128 | pages 111 à 134
}

\footnotetext{
Pour citer cet article :

- SMIRNOVA T., "Byvsie" v uslovijah NEPA : "sirokie perspektivy" ili novye problemy ?, Cahiers du monde russe 2003/1, Vol 44, p. 111-134.
}

Distribution électronique Cairn pour les Editions de l'EHESS.

(C) Editions de l'EHESS. Tous droits réservés pour tous pays.

La reproduction ou représentation de cet article, notamment par photocopie, n'est autorisée que dans les limites des conditions générales d'utilisation du site ou, le cas échéant, des conditions générales de la licence souscrite par votre établissement. Toute autre reproduction ou représentation, en tout ou partie, sous quelque forme et de quelque manière que ce soit, est interdite sauf accord préalable et écrit de l'éditeur, en dehors des cas prévus par la législation en vigueur en France. Il est précisé que son stockage dans une base de données est également interdit. 


\section{«БЫВШИЕ» В УСЛОВИЯХ НЕПА : «ШИРОКИЕ ПЕРСПЕКТИВЫ» ИЛИ НОВЫЕ ПРОБЛЕМЫ?}

Период расцвета новой экономической политики принято считать наиболее либеральным и наиболее «открытым» в советской истории, отличающимся сравнительно «мягким» режимом ${ }^{1}$. Компромисс в экономической сфере в эти годы неизбежно сопровождался компромиссом в сфере социальнополитических отношений, что, в свою очередь, должно было вызвать соответствующие изменения в положении так называемых «бывших людей» или просто «бывших» ${ }^{2}$. Современники по-разному оценивали эти изменения. По словам большевистских лидеров, нэп открывал перед «бывшими» широкие экономические перспективы, возможность взять своеобразный реванш за события 1917 г. В 1921 г. известный партийный деятель, редактор Известий ВЦИК Ю. М. Стеклов писал, в частности:

Новая экономическая политика открывает гораздо более широкие перспективы не только перед буржуазными элементами, и до того игравшими значительную роль в советских учреждениях, но и перед такими, которые раньше стояли в стороне от советского аппарата, и вообще от хозяйственной жизни страны ${ }^{3}$.

1. См. например: М. М. Горинов, «Нэп и возникновение целостной командноадминистративной системы», в сб. Власть и общество России $X X$ век, М. - Тамбов, 1999, с. 88; В. С. Измозик, Глаза и уши режима. Государственный контроль за населением Советской России в 1918-1928 г2., СПб., 1995, с. 258 и др.

2. Под «бывшими» в данном случае подразумеваются не только представители бывших имущих классов, лишенных привилегий в ходе Октябрьской революции 1917 г., но и многочисленный отряд средних социальных слоев, которые по тем или иным причинам были причислены большевистской властью к категории так называемых «бывших людей» или «социально чуждых элементов». Подробнее о социальном пространстве «бывших» см.: Т. М. Смирнова, «“Бывшие”: Штрихи к социальной политике Советской власти», Отечественная история, № 2, 2000, с. 37-48; Она же, «Социальный портрет “бывших” в Советской России 1917-1920 годов. (По материалам регистрации “лиц бывшего буржуазного и чиновного состояния" осенью 1919 г. в Москве и Петрограде)», Социальная история. Ежегодник 2000, М., 2000, с. 87-126.

3. Известия ВЦИК, 7 декабря 1921, с. 1; см. также: А. С. Бубнов, «Экономические предпосылки буржуазного реставраторства», в сб. Буржуазное реставраторство на втором году нэпа, Пг., 1923 и др. 
На первых порах с этим соглашались и сами «бывшие», многим из которых, по словам С. М. Голицына казалось, что наступило «время обещанной свободы». Представитель старинного княжеского рода Голицыных писал позже:

Жители города [Москвы - Т.С.] решили, что каждый может делать что хочет - или ежедневно ходить в учреждение и на предприятие и там добросовестно работать, или превратиться в частника, покупать, продавать, что-то изготовлять, что-то чинить - словом, стараться заработать как можно больше денег ${ }^{4}$.

В то же время Л. Мартов называл новую экономическую политику «чисто зубатовской», подразумевая под этим предоставление экономических уступок при сохранении жесткой политической диктатуры 5 .

Что же в действительности принес «бывшим» нэп: возрождение старых возможностей и надежды на то, что наконец-то «все образуется», или новую «головную боль», необходимость бороться с новыми проблемами и опасностями? 6

\section{«Фронту возрождающейся буржуазной идеологии противопоставить могучий натиск революционной идеологии коммунизма...»}

Несмотря на некоторую либерализацию режима и все явственнее ощущавшиеся в отдельных областях тенденции классового сотрудничества, в действительности о переходе к политике примирения большевистской власти со своими бывшими врагами не было и речи. Собственно, большевики это и не скрывали. Напротив, лидеры РКП(б) неоднократно подчеркивали, что нэп таит в себе опасность возрождения буржуазной

4. С. М. Голицын, Записки уцелевшего, М., 1990, с. 5, 120-121.

5. С. Волин, «Меньшевизм в первые годы НЭПа», Меньщевизм после Октябрьской революции, N.Y., Chalidze publications. 1990, с. 109.

6. Годы нэпа являются крайне неоднородными как с точки зрения декларируемой властью политики, так и (в еще большей степени) с точки зрения реальной политической практики. Общеизвестно, что социально-экономическая политика времен так называемого расцвета нэпа, существенно отличалась от политики его «заката». Причины и сущность этих изменений - сложный вопрос, который не может быть освещен в нескольких предложениях. Проблема внутренней хронологии периода также достаточно сложна и нуждается в специальном рассмотрении. По утверждению некоторых современников курс на «сжатие хозяйственной роли буржуазии» (или, по образному выражению Ю. Ларина, на «вытеснение нэпманов из нэпа, но без его отмены») начался уже в 1924 г. (Ю. Ларин, Интеллигенция и Советь. Хозяйство, буржуазия, госапnарат, М., 1924, с. 19). В 1926-1927 гг. политика ограничения частного предпринимательства не только стала ощутимой, но и принесла первые плоды, массовая же кампания по «искоренению частного предпринимательства» была начата в 1930 г. В данной статье в связи с ограниченностью объема рассматривается период с введения новой экономической политики в 1921 г. до 1925-1926 гг., когда все явственнее стали ощущаться элементы отказа от основных принципов нэпа. 
идеологии и усиления частного капитала, а потому экономические уступки возможны лишь при сохранении политического господства пролетариата и, более того, непременно должны сопровождаться усилением классовой бдительности и идеологического контроля. Выступая в октябре 1921 г. на ХХ Всероссийском съезде политпросветов, В. И. Ленин откровенно подчеркивал:

Мы должны сказать, что должны погибнуть либо те, кто хотел погубить нас и о ком мы считаем, что он должен погибнуть, - и тогда останется жить наша Советская республика, - либо, наоборот, останутся жить капиталисты и погибнет республика 7 .

Опасаясь последствий собственной «классовой либеральности», выразившейся в разрешении частного предпринимательства, а также проведении частичной денационализации и демуниципализации ${ }^{8}$, многие большевистские лидеры призывали компенсировать экономические уступки ужесточением политического контроля. Известный государственный и партийный деятель А. С. Бубнов писал:

Фронту возрождающейся буржуазной идеологии мы должны противопоставить могучий организованный натиск революционной идеологии коммунизма [...] Тут надо пустить в дело все действующие роды оружия, придав и обороне и наступлению максимальную маневренность 9 .

В 1927 г. нарком юстиции РСФСР Д. И. Курский признался, что начиная с 1922 г. ГПУ и НКЮ предприняли «своего рода контратаку», ряд мероприятий, которые «могут характеризоваться как меры не только обороны, но и наступления пролетариата» не только на частника, но и на так называемый «мелкобуржуазный элемент» вообще ${ }^{10}$. Курский, к сожалению, не пояснил, какие именно мероприятия он имел в виду. Если же говорить о социальноэкономической политике в целом, а не только о мероприятиях ГПУ и Нар-

7. В. И. Ленин, Полное собрание сочинений, т. 44, с. 166.

8. Проблемы денационализации и демуниципализации, несмотря на свою значимость с точки зрения характеристики положения «бывших» в годы нэпа, в данной статье не затрагиваются. Тема денационализации традиционно является одним из приоритетных направлений исследований, посвященных нэпу, и потому нет необходимости останавливаться на ей подробно. Проблема демуниципализации, напротив, до сих пор является одним из наименее изученных аспектов нэпа. Именно поэтому автор данной счел необходимым посвятить ее изучению отдельные работы. См.: Т. М. Смирнова, «Жилищная политика Советской власти в годы НЭПа: по материалом демуниципализации в Москве и Московской губернии», Ежегодник историкоантропологических исследований. 2001/2002, М., 2002, с. 276-288; Она же, Демуниципализация домов в годы нэпа: восстановление жилого бонда или обогащение коммунальных служб? (По материалам Москвы и Московской губернии) (в печати).

9. А. С. Бубнов, «Возрождение буржуазной идеологии», Буржуазное реставраторство, указ. соч., с. 25-26.

10. И. С. Кондурушкин, Частный капитал перед советским судом, М.-Л., 1927, с. ХІ. 
комюста, то следует отметить, что «контратака» началась еще ранее. Так, на разных уровнях власти уже в 1921 г. периодически звучали призывы к основательной чистке, как служащих учреждений, так и населения городов (в первую очередь, Москвы и Петрограда). В частности, Ю. Стеклов в декабре 1921 г. указал на необходимость в связи с введением нэпа немедленно провести вслед за партийной чисткой «не менее, если не более строгую» чистку беспартийных, состоящих на государственной службе и, «в первую голову - спецов» 11 . Хотя чистки совслужащих в первой половине 1920-х гг. не приняли столь широкого размаха, как это произошло позже, в конце 20-х - начале 30-х, тем не менее, этот призыв Стеклова был услышан. В частности, в ноябре-декабре 1922 г. была проведена общесоюзная «чистка» безработных от «примазавшихся с целью получения льгот нетрудовых элементов», под которыми подразумевались прежде всего, граждане непролетарского происхождения.

Перерегистрация безработных, проведенная с целью «создания для наиболее ценной и пролетарской рабочей силы таких условий, чтобы последняя как можно скорее получила работу», привела к значительному сокращению их численности ${ }^{12}$. Так, в Саратове численность зарегистрированных безработных сократилась на $40 \%$, в Туле на $37 \%$, в Иваново-Вознесенске - на $35 \%$, в целом же по Республике - примерно на $30 \% 13$. Подавляющую часть «вычищенных» составил так называемый «мелкобуржуазный элемент», пролетаризированный революцией. «Вычищенные» безработные оказались лишены всякой возможности получить работу, а, следовательно, автоматически попадали в категорию людей, «живущих на нетрудовые доходы».

Одновременно со страниц газет и журналов продолжали раздаваться требования уничтожать буржуазию и «слуг капитала», в том числе буржуазную интеллигенцию, которая в силу своей индивидуальной деятельности якобы неизбежно противопоставляется народу. Главный интеллигент страны, нарком просвещения А. В. Луначарский, в частности, утверждал, что «интеллигенция всех цехов, вплоть до школьного учителя», является ни чем иным, как «новым поповством», главная задача которого — «одурачивать массы» ${ }^{14}$. В материалах прессы постоянно ощущалось влияние дихотомичного восприятия властью общества, подразделявшегося на «своих» и «чужых». Символично в этом отношении появление на страницах печати корреспонденции, подписанной псевдонимом «Свой» 15 .

11. Ю. Стеклов, «Еще одна чистка», Известия ВЦИК, 7 декабря 1921, с. 1.

12. А. Исаев, Безработица в СССР и борьба с нею: за период 1917-1924 г2., М., 1924, c. $69-70$.

13. Там же, с. $36,67,70$.

14. А. В. Луначарский, Интеллигенция в ее прошлом, настоящем и будущем, М., 1924 , с. 27 ; см. также: Там же, с. 20, 35, 41-46, 61; Он же, «Концентрация интеллигенции», А. В. Луначарский, Мещзанство и индивидуализм, М.-Пг., 1923, с. 80. 15 См., например: Красная молодежь, № 2, 1924, с. 122. 
Помимо привычных уже форм классовой борьбы, в период нэпа появились и новые специфические формы - высмеивание, окарикатуривание «толстого человека коммерческого типа». Пресса призывала «убивать смехом» классовых врагов, использовать «гиперболу юмора» для «раскрытия их ничтожной сущности» ${ }^{16}$. Как справедливо отметил В. П. Булдаков, «власти сделали все, чтобы окарикатурить образ новых предпринимателей в глазах народа. Нелепая фигура толстого человека во фраке и котелке сделалась непременным атрибутом многочисленных театрализованных шествий» ${ }^{17}$. Яркой иллюстрацией к этому утверждению могут послужить специально разработанные партийными и советскими агитационными отделами, клубными секциями и т.п. органами «инструкции об устройстве массовых зрелищ» и их сценарии. В частности, А. В. Луначарский рекомендовал сопровождать народные празднества выступлениями клоунов с карикатурами на «враждебные силы», поясняя далее: «Хорошо, если в нее влит будет просто безудержный, непосредственный смех» ${ }^{18}$.

Нередко высмеивание сочеталось со скрытой или явной угрозой представителям буржуазного мира. Типична в этом отношении «шутка», опубликованная в 1924 г. в юмористическом журнале Красныцй ворон:

Буржуй о новом мыле: «Оказывается оно великолепно намыливает шею!» Пролетарий: «Еще бы! Шея-то у тебя буржуазная, а мыло - пролетарское» 19 .

\section{«Время обещанной свободы» в условиях политической диктатуры}

«Благотворное влияние приспущенных вожжей новой экономической политики - нэпа — сказывалось всюду, — вспоминал, в частности, С. М. Голицын. [...] На первых порах гнет власти ослаб, арестовывали реже, и то больше уголовников» 20 . Свою жизнь в эти годы в «спиридоновской коммуне» (старинном особняке на Спиридоновке, 18) Голицын вспоминал как веселую и вполне благополучную. По его словам, обитатели спиридо-

16. Подробнее об этом см.: Т. М. Смирнова, «Образ “бывших” в советской литературе», История России ХIX-ХХ веков : новые источники понимания, М., 2001, c. $229-230$

17. В. П. Булдаков, указ. соч., с. 274 ; подробнее об этом см.: И. Б. Орлов, «"Новая буржуазия” в сатире 1920-х гг.», История России XIX-XX вв., указ. соч., с. 230-236.

18. С. Коган, Организация массовых народных празднеств, М., 1921, с. 5. См. также: Октябрь в рабочих клубах: пособие по проведению празднования Октябрьской годовщины, М., 1923; Октябрь: Сборник пособий для проведения праздника Октябрьской годовщины в рабочих клубах, М., 1924; Октябрь в клубах: Сборник материалов к празднованию Октябрьской революции, М., 1924; Как праздновать Октябрь: Пособие для политпросвет работников, М. - Л., 1925, и др.

19. Красный ворон, № 13, 1924, с. 5.

20. С. М. Голицын, указ. соч., с. 120. 
новского особняка «веселились искренно, безмятежно и легкомысленно»: устраивали вечеринки и «кутежи» в ресторане «Прага», катались на лихачах, ходили к Шереметевым на «настоящие балы» с фраками, смокингами и крахмальными рубашками ${ }^{21}$.

Было ли это веселье «пиром во время чумы», как назвал его сам Голицын, или политическая диктатура была не такой уж и жесткой, как казалось Мартову?

Утверждение о сохранении в период нэпа политической диктатуры, будучи безусловно справедливым, тем не менее, не отражает всей сложности и многогранности социально-политической жизни середины 1920-х гг. Ю. Ларин метко охарактеризовал первые 2 года нэпа периодом «сравнительной и довольно относительной терпимости ко все большему выползанию буржуазии на свет.» 22

Эта двойственность социальной политики ощущалась практически во всех сферах жизни: нехотя, «сквозь зубы», но буржуазию терпели, а в чемто и поощряли. Публиковавшиеся в газетах объявления о поиске работы нередко начинались словами «бывший», «интеллигентный», «опытный» (имея в виду наличие дореволюционного стажа) и др.: «бывший нотариус...», «бывшая классная дама...», «опытный инженер с большим административным стажем...», «интеллигентная немка...» и т.д. Наличие на рынке труда столь большого предложения услуг разнообразных «бывших» и «интеллигентных» подпитывалось соответствующим спросом.

Пресса тех лет превратилась в пестрый калейдоскоп, в котором перемешались различные (порой взаимоисключающие) политические и экономические идеи. Требования «четко проводить классовую линию» соседствовали с резкой критикой все возрастающей роли партии и преувеличения значимости партийности и происхождения в оценке человека. Рядом с рубриками «Партийная жизнь», «Советское строительство», «Оздоровление труда и революционизация быта» и т.п. размещалась реклама дорогих ресторанов и кабаре («Веселье день и ночь в ресторане Мартьяныч», «Парижская новинка» - ночной кабаре-концерт «В гостях у Белки» и т.п.), западных кинофильмов, наполненных духом авантюризма («Авантюристка из Монте-Карло. В азарте наживы и конкуренции»), женской косметики («Пудра Адон - идеальное средство для придания коже прелестного, нежного цвета и уничтожения морщин»), гардин с бахромой, уроков маникюра, танцев, хороших манер и изящного почерка, а также прочих атрибутов «мещанского быта», столь осуждаемого новой властью.

В наибольшей степени либерализация режима коснулась «спецов», необходимость которых осознавали даже сторонники радикально «левых» взглядов. «Как зеницу ока» беречь всякого спеца призывал советских и

21. Там же, с. 140, 144-145.

22. Ю. Ларин, Интеллигенция и Советь: хозяйство, буржуазия, революция, zocannapam, М., 1924, c. 19. 
партийных работников В. И. Ленин ${ }^{23}$. Следуя его рекомендациям, ГУКХ НКВД принял ряд инструкций и постановлений о жилищных льготах для научных работников и специалистов ${ }^{24}$. Кроме того, в ряде случаев «особо ценным» работникам предоставлялись дополнительные льготы. Так, в феврале 1924 г. управляющий Центральным статистическим управлением П. Попов обратился к Л. Б. Каменеву с ходатайством о предоставлении в Москве квартиры экономисту П. П. Маслову, известному своим «буржуазным мировоззрением».

\begin{abstract}
Мне нет необходимости писать Вам о том, что работы Маслова, как бы мы не относились к его общей схеме мировоззрения, представляют из себя в области экономики крупный вклад в науку о народном хозяйстве [...] И вот я, как Председатель Сельско-Хозяйственной Секции Госплана, обращаюсь к Вам, как Председателю Московского Совета, с просьбой оказать содействие в предоставлении Маслову квартиры, обеспечивающей ему возможность работать 25 .
\end{abstract}

В отношении к буржуазным спецам, чуждым в идеологическом отношении, но необходимым с точки зрения развития народного хозяйства и функционирования госаппарата, наиболее ярко проявились противоречия социальной политики периода нэпа. Принцип экономической целесообразности нередко одерживал верх над идеями классовой диктатуры. Как справедливо отметила В. Б. Жиромская, «в первой половине 20 -х годов привлечение “старых” специалистов вопреки комчванству партработников было главным источником формирования интеллигенции» ${ }^{26}$. Тем не менее, утверждение некоторых исследователей о том, что буржуазные специалисты достаточно легко «влились в систему» и что в период нэпа противостояние большевиков и специалистов - «не более, чем легенда» представляется несколько упрощенным ${ }^{27}$.

Призывая бережно относится к специалистам, подчеркивая важность их знаний для социалистического строительства, большевистские лидеры в то же время постоянно подчеркивали, что надо, не надеясь на перерождение буржуазных спецов и интеллигенции, идти по пути их полной замены ${ }^{28}$. «Чем скорее мы сможем обходиться без них, - откровенно заявлял

23. В. И. Ленин, Полное собрание сочинений, т. 44. с. 351.

24. См.: Жилищный вопрос: сборник декретов, распоряжений и инструкций разъяснениями, М, 1923, с. 107-112.

25. Центральный Государственный Архив Московской Области -ЦГАМО, ф. 66, оп. 11 , д. 744 , л. 5.

26. В. Б. Жиромская, После революционных бурь: население России в первой половине 20-х годов, М., 1996, с. 115-116.

27. Ш. Плаггенборг, Революция и культура: Культурные ориентиры в период между Октябрьской революцией и эпохой сталинизма, СПб., 2000, с. 329.

28. Ю. Ларин, Интеллигенцзия и Советьл.., указ. соч., с. 36; см. также: Он же, Итоги, пути, выводы, М., 1923, с. 79. 
Луначарский, - тем лучше, ибо они искалечены и самая наука их в большей или меньшей степени отравлена» ${ }^{29}$. Периодические напоминания представителями власти о временном и вынужденном характере сотрудничества со старой интеллигенцией уничтожали с трудом создаваемую «товарищескую атмосферу», о необходимости которой они сами постоянно говорили. «Спец, - пишет, в частности, один из корреспондентов газеты Правда, выражая довольно распространенное в те годы мнение, - это значит: никчемный бездельник, сумевший внушить какому-либо нашему “чудаку" уважение к своим талантам и произведенный этим “чудаком" в “специалисты”.» 30

Периодические «пинки» и насмешки, культивировавшееся прессой презрительно-враждебное отношение к специалистам и интеллигенции в целом порождали ее неуверенность в будущем.

Наряду с противоречивым отношением к специалистам наглядным примером борьбы двух тенденций в социальной политике периода нэпа является так же судебная практика тех лет. Своеобразным отражением эпохи стала развернувшаяся в 1923 г. на страницах газеты Правда дискуссия между Ю. Лариным и И. Смирновым о том, каким должно быть правосудие: профессиональным и беспристрастным или классовым, «заведомо пристрастным в пользу трудящихся». Сетуя на «отсутствие в народном суде классового направления», Ларин требовал провести «основательную чистку личного состава народных судей».

Нам не нужны люди, злопыхательствующие или хотя бы равнодушные к трудящимся. Нам не нужны и люди, одевающиеся в личину бесстрастия (классового нейтралитета) и под видом беспристрастного служения отвлеченной истине и справедливости, ведущие на деле противотрудовую линию [...] в переживаемую эпоху нам нужна не нейтральная слякоть, а судьи, заведомо пристрастные в пользу трудящихся ${ }^{31}$. Пусть лучше менее опытные, да надежные в партийно-классовом отношении [...] Первым делом надо начать снимать с должностей народных судей беспартийных и заменять их коммунистами ${ }^{32}$.

Позднее Ларин сформулировал свою позицию еще откровеннее, предложив вовсе отметить уголовный кодекс и «предоставить суду свободу судить по своему рабочему сознанию без всяких подробных уголовных кодексов» ${ }^{33}$. С Лариным категорически не согласился Смирнов, считавший, что необхо-

29. А. В. Луначарский, Интеллигенция в ее прошлом, настоящем и будущее, указ. соч., c. 35 .

30. Правда, 22 дек. 1922, с. 1.

31. В данном случае выделение текста жирным шрифтом воспроизводится по подлиннику.

32. Ю. Ларин, «О судьях», Правда, 10 ноября 1923, с. 1.

33. Ю. Ларин, Интеллигенция и Советы..., указ. соч., с. 78-79. 
димо привлекать к суду, прежде всего «честных беспартийных рабочих и работниц» 34 .

С развитием нэпа точка зрения Смирнова становилась все более популярной, однако, и сторонников Ларина, придерживавшихся идей революционной целесообразности и суда рабочей совести без «избытка законности», по-прежнему было немало. В их числе и сам Ленин, говоривший в 1922 г., что суды должны «обкорнать» эксплуататоров и бить их по рукам «не так вяло, как делают до сих пор, а помнить, что они - пролетарские суды, окруженные врагами всего мира». Ленин даже предложил «произвести некоторый нажим» на суды в этом отношении ${ }^{35}$. Видимо, именно этими указаниями руководствовались авторы анкеты, которую в 1925 г. было предложено заполнить всем членам Московской губернской коллегии защитников ${ }^{36}$. Из 17 вопросов анкеты 8 так или иначе были посвящены дореволюционному прошлому, среди них: партийность (отдельно до 1905 г., с 1905 по 1917 гг. и после 1917 г.); «социальное положение по происхождению»; профессия до 1917 г. с указанием «всех видов деятельности, которые давали средства к существованию»; имущественное положение и др. Следует подчеркнуть, что вопрос о социальном происхождении был составлен так, что не допускал формальной отписки «служащий», как это часто бывало в то время. Данный пункт анкеты состоял из целого комплекса подвопросов: «социальная принадлежность родителей, источники их существования, краткое описание воспитания и обучения» и другие подробности дореволюционной биографии как анкетируемого, так и его родителей. В соответствии с требованиями составителей анкеты, ответы на все вопросы, касающиеся дореволюционного прошлого, необходимо было подтвердить документально, в крайнем случае - указать лиц, которые могут подтвердить правдивость изложенной информации. Анкету надлежало заверить подписями трех поручителей с указанием конкретных пунктов, которые «удостоверяет» данное лицо ${ }^{37}$.

Таким образом, в середине 1920-х гг. по-прежнему сохранял свою актуальность принцип «тюрьма для буржуазии, товарищеское воздействие - для рабочих и крестьян», провозглашенный в приказе ВЧК от 1 января 1921 г. Тем не менее, на практике судебные решения нередко основывались на нормах нового советского права, а не классовой справедливости, и выносились в пользу «бывших» или нэпманов. Так, например, вынесенное в

34. И. Смирнов, «Один из очередных проектов (ответ тов. Ларину)», Правда, 14 ноября 1923 , с. 1.

35. В. И. Ленин, Полное собрание сочинений, т. 54, с. 98.

36. Распространение анкеты, прежде всего среди членов Коллегии защитников, объясняется, видимо, тем, что в отличие от судей, среди адвокатов было очень много «бывших». Так, к началу 1928 г. из 1260 членов Московской губернской коллегии защитников 1126 имели высшее юридическое образование, в подавляющем большинстве полученное до революции. (ЦГАМО, ф. 165, оп. 1, д. 1567, л. 91.)

37. ЦГАМО, ф. 66, оп. 11, д. 1667, л. 2-3. 
июле 1921 г. исполкомом Яранского уездного Совета решение о конфискации у А. В. Киселева локомобиля, необходимого для оборудования промышленной мастерской уездного совнархоза, было в феврале 1922 г. отменено постановлением народного суда Вятской губернии как незаконное. Апелляция Яранского уисполкома в Наркомюст, СНК и СТО была отклонена, а действия уисполкома были квалифицированы как «домогательства» ${ }^{38}$.

В 1924 г. «классовый принцип» судопроизводства был закреплен утвержденными ЦИК СССР «Основными началами уголовного законодательства СССР». «Основные начала» предусматривали применение «более строгой меры социальной защиты», если обвиняемый «в той или иной мере связан с принадлежностью в прошлом или настоящем к классу лиц, эксплуатирующих чужой труд» (ст. 31, пункт «б»); и, напротив, «мягкой меры социальной защиты» для рабочих и трудовых крестьян (ст. 32, пункт «б») 39 . Однако уже через год был поднят вопрос о недопустимости того, чтобы социальная принадлежность и впредь оставалась фактором «заранее и безусловно определяющим повышение или смягчение меры социальной защиты». В октябре 1925 г. Наркомюст РСФСР вынес на рассмотрение сессии ВЦИК проект изменения некоторых статей основных начал уголовного законодательства. Среди прочих изменений проект предусматривал также исключение социального происхождения и социального положения из группы факторов, отягчающих или смягчающих ответственность лица, совершившего преступление ${ }^{40}$. Проект был отклонен. Тем не менее, в судебной практике середины $1920-x$ гг. социальное происхождение все реже оказывало влияние на решение суда.

Значительно большее влияние на советское судопроизводство в годы нэпа оказывал принцип материальной заинтересованности как адвокатов (на законной основе в виде гонораров), так и судей (на нелегальном уровне в форме взяток).

Комиссии РКИ, регулярно проверявшие работу юридических служб, не раз отмечали, что бесплатная юридическая помощь обычно оказывалась «наспех, небрежно и неряшливо». Совсем другое дело, если клиент мог хорошо отблагодарить своего адвоката. Так, например, бесплатному клиенту Сотникову на его запрос о праве получения освободившейся в их квартире проходной комнаты Юридическая консультация Московской губернской коллегии защитников ответила, что комната автоматически переходит к домоуправлению. Напротив, платному клиенту, в аналогичной ситуации та же консультация назначила защитника для возбуждения дела

38. ГА РФ, ф. Р-130, оп. 6, д. 1056, л. 66-71.

39. СЗ, № 24, 1924, ст. 205.

40. Я. Бранденбургский, «Вопросы уголовного законодательства на сессии ЦИК Союза», Известия ВЦИК, 6 февр. 1927, с. 6. 
против домоуправления с целью получения освободившейся комнаты ${ }^{41}$. В обоих случаях принцип материальной заинтересованности одержал уверенную победу над принципом «классовой справедливости». «Находясь в полной материальной зависимости от клиента, - констатировала комиссия РКИ, - защитник вынужден отстаивать его интересы, которые сплошь и рядом идут вразрез с требованиями закона и политикой правительства» 42 .

Даже в случае неблагоприятного для богатого клиента исхода дела, по свидетельству современников, ему нередко удавалось каким-либо образом избежать исполнения приговора. Так, по утверждению помощника прокурора СССР И. С. Кондурушкина, бывший миллионер-металлоторговец С. Пляцкий в 1925-1926 гг. проходил по 18 судебным процессам, каждый раз был признан виновным и каждый раз благополучно возвращался к предпринимательской деятельности. «По всем делам осужден, но по всем делам жив и здоров поныне, - недоумевает Кондурушкин. - [...] Два раза попадал в ЧК и оба раза возрождался, как феникс.» 43

Подобные случаи были настолько широко распространены, что регулярно (впрочем, безрезультатно) высмеивались в сатирических журналах тех лет. В частности, типичной для периода нэпа является фельетон об Иване Петровиче, заведующем отделом закупок, и Петре Ивановиче, заведующем отделом продаж учреждения, которое «все покупало (по большей части за очень высокую цену) и все продавало (по большей части за очень низкую цену)». Иван Петрович и Петр Иванович были арестованы за спекуляцию и хозяйственные махинации и приговорены к расстрелу. «Смертная казнь, - пишет далее автор фельетона, - была заменена 10летней отсидкой, и Иван Петрович и Петр Иванович до сих пор сидят... в двух смежных комнатах в том учреждении, которое все покупает и все продает.» 44

Если верить члену Президиума ЦКК ВКП(б) А. А. Сольцу, даже в советских тюрьмах взяточники и нэпманы находились в привилегированных условиях, их хорошо кормили, отпускали «на работы в учреждения», а также домой, повидать семью ${ }^{45}$. По словам И. С. Кондурушкина, спекулянты, проходившие по трем-четырем и более делам, нередко «легко отделывались, потому что кто-то за них просил, ходатайствовал по чьей-то еще просьбе, даже лично их не зная». Кондурушкин продолжает:

В случаях судебной высылки спекулянтских элементов из центральных городов, не проходит несколько месяцев, как высланный, т.е. социально опасный

41. ЦГАМО, ф. 165 , оп. 1, д. 1567, л. 10-15.

42. Там же, л. 15.

43. И. С. Кондурушкин, Частный капитал перед советским судом, М.-Л., 1927, с. 7071; См. также: Ю. Ларин, Частный капитал в СССР, М., 1927, с. 450-452.

44. О. Л. Д’Ор , «Даешь, берешь», Красный ворон, № 1, 1922, с. 5.

45. А. Ли-н, «Суд: о том, как люди попадают в тюрьму», Беднота, 18 окт. 1923, с. 8. 
для нас человек, заводит на месте служебные знакомства и оказывается на ответственной работе [...] Нередки ходатайства ответственных работников за спекулянтов только потому, что этот спекулянт был когда-то хозя и ном 46 ныне ответственного работника, который раньше был, положим, у теперешнего спекулянта кучером 47 .

Любопытно, что требованиям закона и принципам классовой справедливости противоречили порой не только частные, «шкурные» интересы взяточников и платных адвокатов, но и экономические интересы самого государства. Борьбу двух основных тенденций периода - политкорректности, с одной стороны, и прагматизма, с другой, - наглядно отражают крутые зигзаги советского судопроизводства при рассмотрении дел специалистов. Так, например, в конце ноября 1920 г. Донской областной ревтрибунал за взяточничество приговорил к расстрелу бывшего директора-распорядителя торгового отдела Донского Совета народного хозяйства (ДСНХ) И. И. Рахлина и бывшего начальника административного управления ДСНХ М. П. Купермана. Суровый приговор был мотивирован, «во-первых, классовым происхождением обвиняемых: представители буржуазии, затесавшиеся в советские учреждения». В сентябре 1921 г. дело было пересмотрено, и, несмотря на чуждое, непролетарское происхождение обвиняемых, расстрел был заменен лишением свободы в исправительном доме со строгой изоляцией сроком на 10 лет. Однако, принимая во внимание «чистосердечное раскаяние обвиняемых и честное слово, данное суду в том, что они своими знаниями и трудом окупят свою вину перед Советской Республикой», в том же месяце новый приговор был заменен заключением в исправительный дом без изоляции «с принудительной работой по специальности». Учитывая специальность обвиняемых, заключительный приговор приобретает несколько комичный характер. «Их специальность, недоумевает по этому поводу описавший эту историю журналист А. Львов, — “ответственный работник" [...] Вот их, по приговору суда, в этой “специальности” и должны использовать.» 48 Как тут не вспомнить историю об Иване Петровиче и Петре Ивановиче?

Помимо юридической практики можно привести немало других примеров, когда центральные и местные власти, судебные органы, а также прочие ответственные советские и партийные работники разных уровней в своих решениях исходили из принципа экономической целесообразности или буквального следования юридическим нормам (а то и просто руководствовались личными интересами) в ущерб провозглашенным классовым приоритетам.

46. Выделение текста «в разрядку» воспроизводится по подлиннику.

47. И. С. Кондурушкин, указ. соч, с. 203, 204, 205.

48. Правда, 22 дек. 1922 , с. 1. 
Ярким примером «классового либерализма» этого периода являются предпринимавшиеся в Москве в начале 1920-х гг. новации в области учета населения 49 .

После окончания гражданской войны в Советской Республике встал вопрос об организации централизованной государственной системы учета населения по единому образцу с целью устранить ту «вакханалию имеющихся разнообразных видов на жительство» (старые паспорта, трудовые книжки, временные свидетельства разного рода, удостоверения о личности и пр.), в которых, по признанию членов Комиссии Моссовета по переучету населения, даже опытные работники затруднялись разобраться ${ }^{50}$. Если в деревнях и маленьких городках, где все знали друг друга в лицо, отсутствие личных документов единого образца не создавало особых проблем, то в крупных городах и в масштабах всего государства это существенно затрудняло организацию снабжения населения продовольствием, строительство сети детских школьных и дошкольных учреждений, равномерное распределение трудовых ресурсов и т.п. ${ }^{51}$ По свидетельству сотрудников отдела управления Моссовета, через который проходили документы практически всех, кто приезжал в столицу в поисках работы, в подавляющей части разнообразных удостоверений личности, выдаваемых на местах в 1918 - начале 1920-х гг., сведения о происхождении либо отсутствовали, либо были указаны неопределенно ${ }^{52}$. Так, например, в Московской губернии учет населения велся в этот период в основном по волостным «семейным спискам». Эти списки включали в среднем 6-14 вопросов, среди них обязательными, помимо полного имени и года рождения, были следующие: отметка о выдаче видов на жительство, отметка о розыске следственными органами и о дезертирстве, отметка о смерти, о «безвестном отсутствии» и «выбытии из членов семьи» по другим причинам; реже - о национальности, образовании, перемене места жительства и т.п. Пункты с

49. Проблема учета населения, особенностей становления паспортной системы в Советской России является сложной и многогранной. В данной статье затрагиваются лишь отдельные ее аспекты, непосредственно касающиеся положения «бывших» и проводимой по отношению к ним политики.

50. ЦГАМО, ф. 66, оп. 12, д. 1056а, л. 13-14.

51. По утверждению некоторых исследователей, советская система учета населения имела преимущественно полицейские функции, такие как «надзор за трудовой деятельностью», облегчение «политического преследования» и т.д. (См., например: М. Мэтьюз, «Ограничения свободы проживания и передвижения в России (до 1932 года)», Вопросы истории, № 4, 1994, с. 32-33). Не отрицая значимость надзорных и политических целей проводившихся в послереволюционной России учетнорегистрационных мероприятий, нельзя игнорировать также и экономические, демографические и даже социальные (учет инвалидов и пенсионеров в отделах социального обеспечения, учет детей школьного возраста органами Наркомпроса и т.д.) цели учета населения.

52. ЦГАМО, ф. 66, оп. 12, д. 1056а, л. 89. 
вопросами о социальном происхождении в волостных «семейных списках» начала 20 -х гг. практически не встречаются ${ }^{53}$.

Образовавшаяся за период революции и гражданской войны путаница в личных документах граждан особенно заметна была в столице, куда съезжались люди из разных концов страны. Вот как охарактеризовал сложившуюся к началу нэпа ситуацию управляющий делами Моссовета П. П. Салов:

Большое разнообразие видов на жительство представляет затруднения разобраться в их подлинности [...] В Москву приезжают граждане со всех сторон РСФСР, имея на руках:

1) старые годовые, пятилетние и бессрочные паспорта;

2) удостоверения, выданные волсоветами;

3) удостоверения, выданные сельсоветами и написанные на клочке бумаги или газетном отрывке с приложенной лепешкообразной печатью из какой-то копоти;

4) разнообразные свидетельства и удостоверения, выданные органами милиции;

5) командировочные удостоверения с указанием лишь должности, имени и фамилии;

6) иностранные виды на жительство;

7) оптационные удостоверения;

8) паспорта, выданные органами власти иных советских республик 54

Начиная с 1921 г., Салов неоднократно предлагал ввести единую государственную систему учета населения, причем в предлагаемой им системе учета не предусматривалось никакого различия между гражданами по их социальному происхождению. По мнению Салова, по окончанию гражданской войны сведения о социальном происхождении граждан вообще перестали иметь значение; каждому ведомству нужна лишь конкретная информация, необходимая для работы подведомственных учреждений. «Военный комиссариат, - писал Салов, - при учете населения может обойтись без фамилий, происхождения и большинства вопросов личной карточки. Военному комиссариату нужны лишь точные сведения о количестве военнообязанных, подразделении их по годам рождения, родам оружия». Органам Наркомата труда «необходим учет состоящих на службе по возрасту, полу, профессии и, в частности, лиц безработных»; а органам Наркомпроса «сведения о количестве малолетних по годам рождения» 55 . В апреле 1921 г. Салов предложил разделить все население Республики на 3 основные группы: 1) несовершеннолетние (до 16 лет); 2) трудоспособные; 3) инвалиды труда и войны, а также прочие нетрудоспособные. «От первой группы населения, - пояснял Салов, - государство ничего не требует, а, нао-

53. См., например: Там же, л. 25, 72, 74.

54. Там же, л. 89.

55. Там же, л. 22-23. 
борот, государство обязано воспитывать эту группу населения и снабжать всеми видами довольствия». С третьей группой «дело должен иметь только НК социального обеспечения, а прочие наркоматы к этой группе никаких требований не предъявляют» 56 . Таким образом, об учете социального происхождения населения не было и речи.

На фоне подобной классовой терпимости московских властей вызывают удивление неоднократно повторявшиеся в эти годы местными властями, включая и Моссовет, требования провести «основательную чистку» города.

\section{«Очистить города от социально опасных элементов»}

Требования «очистить город» и прочие меры, предпринимаемые в период нэпа против «социально опасных элементов», традиционно являются одним из важнейших аргументов сторонников широко распространенного в последние годы утверждения о не прекращавшихся жестоких репрессиях большевиков против «бывших». Действительно, в середине 1920-х гг. на фоне общей либерализации режима происходило ужесточение репрессивной политики государства против так называемых «социально опасных» (или «социально вредных») элементов. Однако правомерно ли отождествление их с «бывшими»? А. Черных, например, утверждает, что на протяжении всего первого послереволюционного десятилетия именно «бывшие» рассматривались властью как «социально опасные элементы» 57 . Сами же представители большевистской власти зачастую трактовали данную группу населения совершенно иначе.

Четких границ социального пространства так называемых социально вредных (или социально опасных) элементов нет. В зависимости от конкретной ситуации и личных убеждений того или иного представителя власти эти границы то расширялись, то сужались. Однако можно с уверенностью сказать, что в подавляющем большинстве случаев критерием идентификации «социально опасных» в годы нэпа было не столько социальное происхождение, сколько экономический ущерб, наносимый деятельностью данных людей, или потенциальная опасность этой деятельности для общества. Очевидно, что пространство «социально вредных элементов» неизбежно в

56. Как и следовало ожидать, предложение Салова не было реализовано на практике. Вплоть до 1923 г. личные учетные документы единого образца введены не были. 20 июня 1923 г. декретом ВЦИК были введены удостоверения личности, в которые вносились следующие сведения: имя, дата рождения, место постоянной прописки, основная профессия, отношение к воинской обязанности, семейное положение, количество детей в возрасте до 16 лет, личная подпись, место и дата выдачи, подпись лица, выдавшего удостоверение, и печать. Удостоверения личности выдавались сроком на 3 года. Старые паспорта, виды на жительство и трудовые книжки аннулировались с 1 января 1924 г. (СУ, № 61, 1923, ст. 575.)

57. А. И. Черных, Становление России советской: 20-е годы в зеркале социологии, M., 1998, c. 262. 
значительной мере пересекалось с пространством «бывших», но не совпадало с ним полностью.

Понятие «социально опасные элементы» (СОЭ) было введено в советскую юридическую практику Уголовным кодексом РСФСР 1922 г., статья 7 которого предусматривала возможность применения наказания по отношению к лицам, чья деятельность «обнаруживает» их опасность для общества $^{58}$. В соответствии с декретом ВЦИК от 16 октября 1922 г. о дополнении к постановлению «Об административной высылке», социально-опасными считались все деятели антисоветских политических партий, а также лица, дважды судившиеся за бандитизм, грабеж, кражу или разбой; подделку денежных знаков и государственных бумаг; изготовление, приобретение и хранение взрывчатых веществ или снарядов, а также хранение без разрешения огнестрельного оружия; самогоноварение с целью сбыта и фальсификацию предметов потребления; принуждение к проституции, сводничество и содержание притонов; хулиганство ${ }^{59}$. Инструкция НКВД по применению постановления об административной ссылке от 3 января 1923 г. шире истолковывала понятие СОЭ, включив в его пространство всех лиц, которые могли представлять опасность с точки зрения охраны революционного порядка «по их деятельности, прошлому, связи с преступной средой» 60 . Что конкретно подразумевалось в данном случае под «прошлым» - происхождение, политическая деятельность или уголовные преступления - остается неясным.

Как трактовалось понятие СОЭ в социально-политической практике, можно проследить по материалам периодически проводившихся в 1920-е годы кампаний «чисток» столицы от социально опасных элементов. В 19221923 гг. отдел управления Моссовета, как уже упоминалось выше, настойчиво призывал к «основательной чистке Москвы» от СОЭ. Кого же конкретно предлагали выселить из столицы и почему?61

58. Сборник документов по истории уголовного законодательства СССР и РСФСР: 1917-1952 г2., М., 1953, с. 117.

59. Там же, с. 149.

60. Там же, с. 155-156. Аналогичное толкование социально-опасных лиц сохранилось и в УК РСФСР редакции 1926 г. (Там же, с. 257-258).

61. Понятие «чистка» имело в 20-30-е гг. различное значение. Наряду с кампаниями социально-политического характера (партчистки, чистки соваппарата, чистки безработных и т.п.), оно употреблялось и для обозначения мероприятий санитарногигиенического, противоэпидемического характера. Так, 26 июля 1919 г. Исполком Моссовета принял решение провести в городе «общую генеральную чистку», имея в виду мероприятия, необходимые для предупреждения эпидемии сыпного тифа. (Красная Москва: 1917-1920 г2., М., 1920, стб. 28). Подобные решения регулярно принимались в 1918-1919 гг. в связи с крайне тяжелой санитарно-гигиенической ситуацией в столице. В литературе (как популярной, так и научной) нередко можно видеть смешение данных понятий, когда любые упоминания об «основательных чистках» города истолковываются исключительно как акции классовой борьбы, что приводит к искаженному отражению исторической реальности. 
В декабре 1922 г. начальник отдела управления Моссовета В. Л. Орлеанский объяснил необходимость «чистки» столицы тем, что в ней «наблюдается вспышка вооруженных налетов на квартиры и уличных ограблений». Далее Орлеанский уточнил, что нужно как можно скорее очистить Москву от бандитов, «особенно квалифицированных рецидивистов, в том числе с дореволюционным стажем» 62 . Именно «квалифицированные рецидивисты» и составляли, с точки зрения руководства отдела управления Моссовета, основу так называемых социально опасных элементов. Помимо «уголовной среды» (воров, насильников, убийц, торговцев морфием и кокаином) и связанных с ними лиц (перекупщиков краденого и содержателей притонов), в число СОЭ включали аферистов, шулеров, игроков на бегах, гадалок, «целителей» и прочие категории граждан, чья деятельность находилась на грани уголовного преступления. Если среди аферистов действительно чаще встречались выходцы из «бывших» (что не удивительно, так как подобная деятельность требовала определенного интеллектуального уровня и знаний), то среди воров и убийц подавляющую часть составляли крестьяне и рабочие. В частности, Кабинет по изучению личности преступника при Мосздравотделе, обследовав 2600 правонарушителей, прошедших через Московское управление уголовного розыска (МУУР) в 1925 г., сделал вывод об «абсолютном преобладании» среди них рабочих и крестьян, в то время как представители интеллигенции, промышленники, «зажиточные» и «средне богатые» дали минимальный процент правонарушений ${ }^{63}$. К аналогичным выводам пришел и В. Р. Якубсон, проанализировавший в конце 1920-х гг. «добытые разными способами, по различным источникам и за разное время» данные о социальном составе лиц, осужденных после революции за уголовные преступления ${ }^{64}$. Эти данные косвенным образом подтверждаются также Ю. Лариным и И. С. Кондурушкиным, по подсчетам которых около 25 \% государственных служащих, осужденных в 1921-1923 гг. за хозяйственные преступления, имели только низшее образование, были самоучками либо совершенно неграмотными 65 .

Столица как магнит притягивала к себе всяческий «уголовный элемент». Л. Шейнин, бывший в то время следователем МУУРа (позднее МУРа), писал о годах нэпа:

А в городе [Москве - Т.С.] невесть откуда и черт его знает зачем, повылезла из всех щелей всякая нечисть — профессиональные шулера и надменные кокотки, спекулянты с воспаленными от алчности лицами и

62. Известия ВЦИК, 31 декабря 1922, с. 4.

63. Е. К. Краснушкин, «Что такое преступник», Преступник и преступность, М., 1926, c. 27.

64. В. Р. Якубсон, «Кто находится в местах заключения?», Административный вестник, № 4, 1929, с. 48.

65. Ю. Ларин, Частный капитал.., указ. соч., с. 443. 
элегантные, молчаливые торговцы живым товаром, бандиты с аристократическими замашками и бывшие аристократы, ставшие бандитами, эротоманы и просто жулики всех оттенков, масштабов и разновидностей 66 .

17 октября 1923 г. в связи с перенаселением столицы, сопровождавшимся острым жилищным кризисом, безработицей, ухудшением санитарно-гигиенического состояния города, угрозой эпидемий и обострением криминогенной ситуации, комиссия по разгрузке г. Москвы при СНК РСФСР представила на рассмотрение СНК проект постановления об ограничении въезда в столицу и о порядке высылки из города некоторых категорий граждан. В первую очередь предполагалось выслать из столицы все социально вредные элементы (но только после рассмотрения каждого конкретного случая Московским губернским судом). В соответствии с проектом, к таковым были отнесены следующие категории населения: а) «лица, не связанные с производительным трудом в государственных, общественных или частных предприятиях и учреждениях»; б) «лица, не имеющие определенных общественно-полезных занятий или профессий или не могущие указать источников своего существования»; в) лица, связанные с преступной средой ${ }^{67}$. Таким образом, в основу определения «социальной вредности» того или иного лица брался признак социального положения, а не социального происхождения. Для доработки проекта была создана комиссия Малого СНК под председательством Н. В. Крыленко. Комиссия признала нецелесообразным включение в постановление пункта «а», из-за своей неопределенности допускающего выселение любого, кто не работал по старости или по состоянию здоровья, всех безработных, а также всех лиц свободных профессий, чей труд не связан с производством материальных благ. Пункт «б» в новом проекте был дополнен весьма существенным уточнением: «...и не зарегистрированных на бирже труда», что ограждало от высылки официальных безработных. Третий пункт был расширен: помимо лиц с уголовным прошлым, выселению подлежали также профессиональные игроки на бегах, шулеры, аферисты, содержатели притонов, торговцы кокаином, морфием, самогоном и т. п. лица, которых невозможно было предать суду за недостаточностью улик. Новый проект был принят Малым СНК 21 декабря 1923 г., однако уже 10 января 1924 г. это решение было отменено СНК. Главной причиной отклонения проекта стало заключение Наркомата юстиции, о том, что проект «оставляет возможности для злоупотреблений». В постановлении говорилось также, что в настоящий момент СНК признает принятие декрета об ограничении въезда в Москву и о порядке высылки из Москвы нецелесообразным и нежелательным 68 .

66. Л. Р. Шейнин, Записки следователя, М., 1979, с. 4.

67. ЦГАМО, ф. 66 , оп. 11, д. 521, л. 88.

68. Там же, л. 91-92. 
Несмотря на неоднократные протесты Президиума Моссовета, подчеркивавшего, что перенаселенная столица стоит на пороге эпидемий, 3 апреля 1924 г. ВЦИК подтвердил решение СНК о нежелательности декрета об ограничении въезда в столицу и о порядке высылки из нее отдельных категорий граждан ${ }^{69}$.

Таким образом, въезд в Москву оставался свободным. Однако выселения отдельных лиц в качестве социально вредных элементов были в эти годы обычным явлением. Не добившись права массового выселения на основании специального декрета, московские власти активно практиковали выселения в индивидуальном порядке по постановлениям ГПУ или Административного отдела Моссовета. Одной из наиболее распространенных причин выселения из столицы было «введение в заблуждение несознательных слоев населения путем занятия хиромантией» и прочие подобные действия, получившие большое распространение в годы нэпа ${ }^{70}$. Основную же массу высылаемых из Москвы в качестве СОЭ, составляли выходцы из крестьян и рабочих, успевшие за послереволюционные годы получить по несколько судимостей за уголовные преступления ${ }^{71}$.

Очевидно, что местные власти при выявлении социально опасных лиц далеко не всегда руководствовались исключительно юридическими нормами. Да и нечеткие формулировки инструкций оставляли возможность достаточно произвольного их толкования, как под воздействием собственного «пролетарского чутья», так и в корыстных целях (сведение личных счетов, освобождение приглянувшейся квартиры или должности и т.д.). Однако и в этом случае наиболее пострадавшими оказывались средние социальные слои, выходцы из мещан, тяжелым трудом скопившие небольшое состояние, но не имевшие необходимых связей, высокой квалификации или средств, достаточных для того, чтобы откупиться от не чистых на руку представителей власти. Типичным в этом отношении примером может служить судьба Н. Ф. Голованова.

Выходец из бедной мещанской семьи Н. Ф. Голованов с 13 до 54 лет проработал на табачной фабрике Босанжоглу, начав службу «мальчиком» и дослужившись до заведующего папиросным отделом. В 1916 г. он был

69. Там же, л. 107.

70. Целители, гипнотизеры, хироманты и прочие представители оккультных наук зарабатывали в эти годы огромные деньги, наживаясь на невежестве широких масс населения. «У нас в клубе, - рассказывал, в частности, рабкор газеты Гудок в 1925 г., - был вечер прорицательницы и гипнотизерки Жанны. Угадывала чужие мысли и заработала 150 рублей за вечер». На основе этого и подобных сообщений, присланных в редакцию газеты, М. А. Булгаков написал фельетон Мадмазель Жанна, в котором описал типичный для тех лет сеанс прорицательства, «построенного исключительно на силах природы с разрешения месткома и культурно-просветительной комиссии и представляющего собою виталлопатию на основе гипнотизма по учению индийских факиров, угнетенных английским империализмом» (М. А. Булгаков, Самоцветный бbım, М., 1985, c. 38-39).

71. См., например: ЦГАМО, ф. 66, оп. 11, д. 521, л. 19, 21, 22, 24-25, 67 и др. 
вынужден уйти с фабрики из-за обострения туберкулеза и с 1918 по 1922 гг. состоял на службе в Центросоюзе и ВСНХ в должности помощника заведующего транспортной частью, откуда был уволен по сокращению штатов. В 1922 г. Голованов был приглашен в только что организованное Товарищество табачной торговли «Сокол» в качестве специалиста по табачному делу. По утверждению Голованова, в товариществе он участвовал не денежными средствами, но только своим опытом и знаниями. Уйдя из товарищества, Голованов оказался на содержании племянников - инженера Московских городских железных дорог И. Д. Цыбульского и юрисконсульта «Госселькожи» К. И. Логинова. 7 января 1924 г. квартира Голованова в его отсутствие была опечатана сотрудниками ГПУ. Для выяснения обстоятельств Голованов явился в ГПУ, где и был арестован. Через 12 дней его отпустили, предварительно взяв письменное обязательство в семидневный срок выехать из Москвы без права проживания в Петрограде, Киеве, Одессе, Ростове-на-Дону. Никакое обвинение Голованову предъявлено не было, но на словах ему объяснили, что он высылается из столицы как социально вредный элемент. В отчаянии Голованов обратился в Президиум Моссовета с прошением, в котором, в частности, писал:

Я никогда ни за что не был судим. За время Советской власти спекуляцией, посредничеством не занимался, никаких ни с кем сделок торгового характера не заключал, на «черной бирже», на бегах, в казино никогда не бывал и вообще ничего предосудительного не совершал. Наложенное на меня взыскание - высылка, является недоразумением: здесь произошла какая-то ошибка. Подчиняясь распоряжению ГПУ, я оставляю Москву — выезжаю в город Кинешму, но молю Президиум Московского Совета о справедливости — прошу сделать распоряжение о пересмотре моего дела. Если я по какимлибо причинам (по старости моей или неспособности к труду), не могу быть возвращен в Москву, то прошу не оставлять меня-старика на верную гибель в чужом для меня месте (г. Кинешма), а разрешить мне проживание у сестры моей - Антонины Клепиковой в Бронницком уезде Московской губернии без права въезда в Москву.

Президиум Моссовета сообщил Голованову (без объяснения причин), что пересмотр дела «не представляется возможным» 72 .

С середины 1920-х гг. началось массовое (списками, без рассмотрения каждого конкретного дела судом или административными органами) выселение из крупных городов т.н. «накипи нэпа». Эта акция распространялась в основном на мелких торговцев, практически не коснувшись крупных нэпманов. В частности, по свидетельству Ю. Ларина местными властями западных городов СССР было предпринято выселение мелких торговцевевреев в Южную Украину и Крым, где им давали землю для организации трудовых земледельческих хозяйств. Ларин писал в 1927 г.:

72. Там же, л. 2a-7. 
Это продолжается уже четыре года, переселилось уже около 100 тыс. чел., и результаты оказываются хорошими. Люди превратились в настоящих крестьян, так что в этом году многим из них дано уже избирательное право. Они находятся под контролем местных органов, и установлено, что они действительно сами работают физически, живут в землянках, ведут тяжелый образ жизни, но организуют хозяйство.

В то же время вопрос о массовом выселении из Москвы и других городов с населением более 50 тысяч лиц так называемой «уголовной буржуазии» (т.е. крупных нэпманов, когда-либо ранее подвергавшихся уголовному преследованию или административным взысканиям в связи с обвинениями по хозяйственным делам) был поднят лишь в 1926-1927 гг. ${ }^{73}$. На практике же к массовым выселениям наиболее крупных представителей «советской буржуазии» приступили лишь в 1930-е гг.

Очевидно, что, с точки зрения положения в Советской России так называемых «бывших людей», годы нэпа не могут быть охарактеризованы однозначно. По-своему правы были и Ю. М. Стеклов, считавший, что нэп открыл перед бывшей буржуазией «новые широкие перспективы», и Л. Мартов, утверждавший, что, несмотря на экономические уступки, в годы нэпа по-прежнему сохранялась политическая диктатура. С одной стороны, новая экономическая политика действительно открывала неплохие возможности для частного предпринимательства, развития инициативы и быстрого обогащения. Однако возможность на практике воспользоваться экономическими уступками нэпа определялась не столько бывшим социальным и имущественным положением, сколько психологическими особенностями человека, его умением быстро ориентироваться в ситуации, приспосабливаться к новым условиям, заводить нужные связи и т.п. В частности, значительная доля недвижимости, подлежащей демуниципализации или денационализации, вопреки обещаниям отнюдь не была возвращена бывшим собственникам, а попала в руки «нужных» людей, так или иначе связанных с местными властями ${ }^{74}$. Как справедливо отметил С. В. Шейхетов, детально изучивший биографии нэпманской «верхушки» Сибири и обработавший 100 личных дел нэпманов-середняков Новониколаевска, «большинство нэпманов относилось к тому типу людей, которые одинаково неплохо чувствуют себя в любые времена и при любых условиях». Шейхетов продолжает:

Они сумели занять достаточно высокие позиции в социальной иерархии как общества 20-х, так и общества 30-х. После окончания НЭПа многие частные предприниматели стали работать на руководящих должностях на государственных и кооперативных предприятиях, быстро адаптировавшись к новым условиям. Данный факт также говорит в пользу незаурядности этих людей.

73. См.: Ю. Ларин, Частный капитал в СССР, указ. соч., с. 445, 452.

74. Подробнее об этом см.: Т. М. Смирнова, Жилищная политика.., указ. соч., Она же, Демуниципализация домов... указ. соч. 
Причем эта незаурядность выглядит особенно рельефно на фоне огромного количества так называемых «бывших», то есть дворян, офицеров, царских чиновников, многих представителей интеллигенции, так и не сумевших найти свое место в послереволюционном обществе ${ }^{75}$.

Иначе говоря, далеко не все «бывшие» влились в ряды нэпманов, и далеко не все нэпманы происходили родом из «бывших». Нельзя также забывать и о том, что экономические уступки частнику носили временный и вынужденный характер. Наиболее предусмотрительные из представителей бывших имущих слоев прекрасно это понимали и не спешили вновь обзаводиться недвижимостью и рисковать с трудом припрятанными капиталами, а то и собственной свободой. Редакция газеты Известия ВЦИК писала по этому поводу:

Спросим любого буржуа, почему он не спешит воспользоваться правами, которые дают ему новые декреты, почему он не берет в аренду предприятий, не вносит денег на текущий счет и т. д. Мы услышим категорический ответ: «Я не верю, что это всерьез и надолго, а главное, когда через каждую пару строк я читаю в ваших декретах — “диктатура пролетариата”, — вся “свобода" теряет для меня цену.» 76

Как показала сама жизнь это «неверие» было вполне оправданным. Начиная с 1927-1928 гг. пресса и местные власти все чаще употребляли такие понятия, как «бывшие», «нетрудовые элементы» или «нэпмановские элементы», в качестве тождественных. Так, к нетрудовым элементам был причислен, например, пекарь, имевший собственную пекарню, хотя и работавший без применения наемных рабочих ${ }^{77}$.

Выступая в декабре 1929 г. на Всесоюзной конференции аграрниковмарксистов, И. В. Сталин откровенно признался, что придерживаться новой экономической политики следует лишь до тех пор, пока она служит делу социализма, а «когда она перестанет служить делу социализма, мы ее отбросим к черту» 78 . Как только нэп был окончательно «отброшен к черту», все новые хозяева и торговцы из рабочих и крестьян были объявлены перерожденцами, разложившимися элементами и в конце концов, пополнили ряды «бывших», равно став «чуждыми» советской власти, независимо от своего происхождения.

Таким образом, для подавляющей массы средних слоев «бывших» обещанные с началом нэпа «широкие перспективы» на деле оказались весьма

75. С. В. Шейхетов, «Нэпманы Сибири», Электронный журнал «Сибирская заимка». www.zaimka/ru/soviet/cheikh.

76. «Коммунисты в мелкобуржуазном окружении», Известия ВЦИК, 12 авг. 1921, c. 1 .

77. ГА РФ, ф. Р-130, оп. 6, д. 316, л. 49.

78. И. В. Сталин, «К вопросам аграрной политики в СССР», Вопросы ленинизма, М., 1953, c. 326. 
ограниченными. Пожалуй, наиболее значимым послаблением для них в этот период было то, что классовый принцип сохранял свой приоритет лишь в теории, на деле же верх все чаще одерживал принцип экономической целесообразности либо личная заинтересованность должностных лиц. На какое-то время основной удар репрессивной политики советской власти был перенесен с социально чуждых слоев на все более разраставшуюся уголовную среду. В остальном же, как метко подметил некий «И.Ф.» в написанном им в 1922 г. стихотворении, власть лишь сменила «ежовые рукавицы» на «ежовые перчатки»:

Пусть те, кто на соблазны падки,

Все ж не выходят из границ...

Нэп - не реакции начатки:

Он лишь - ежовые перчатки

Взамен ежовых рукавиц ${ }^{79}$.

Российская Академия наук

Институт российской истории

svzhuravlev@mail.ru 